$\xi=-1$

\title{
The Requirement of Records Management Practices for Institutional Audits
}

\author{
*Nik Nurul Emyliana Nik Ramlee${ }^{1}$, Saiful Farik Mat Yatin ${ }^{1}$, Mastura Md Zali ${ }^{1}$, Nurul Aiqa Mohd Zain ${ }^{1}$, Amzari \\ Abu Bakar', Wan Satirah Wan Mohd Saman', Raja Ahmad Iskandar Raja Yaacob ${ }^{2}$

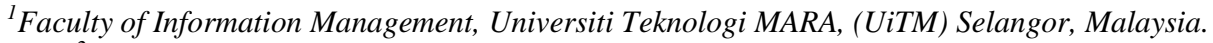 \\ ${ }^{2}$ Management and Humanities Department, Universiti Teknologi Petronas, Malaysia \\ *Corresponding author: *Nik Nurul Emyliana Nik Ramlee: Faculty of Information Management, Universiti Teknologi MARA, (UiTM) \\ Selangor, Malaysia. \\ E-mail: emyliananick@yahoo.com
}

\begin{abstract}
Currently, the issues of corruption or white-collar crime rise in government sector and this issue raised during the audit checking. The organization itself do not take the initiative and follow the policy and standard assigned by the government when manage the records in their organization with the requirement of records management practices. This study also emphasizes the role of records management in conducting the risk mitigation in governance regarding the auditing process, the relationship of the records management and good governance and to analyse the general report of one organization in Malaysia which related with the audit department. With this study, hopefully the good governance and accountability could be achieved and the crime rate could be minimized as well as no litigation occur during the auditing process if the records management practices plays their roles. This study is to investigate the impact of the implementation of good records management practice in exercising good governance and to ease up the auditing process.
\end{abstract}

Keywords: Records Management, Audit, Good Governance, Risk Management

\section{Introduction}

Records management practices are the areas of necessity for the organization to deal with the transaction that covered the life cycle of records, which is from the creation of transaction, use, maintenance and disposition of the documents and records. When records management system functioning well, the information contained in records can be readily retrieved, and facilitating administration. As well, it is easier to manage the disposal of unneeded records and the retention of valuable information. However, records management practices still being neglected by the organization in providing and utilizing the requirements as the supporting documents in order to provide evidence and as the decision making to solve these problems. The records management program indeed has been implemented in the organization, however the organization itself not really take the initiative to follow the requirements and adapt the records management environment in their transaction of business especially in audit unit or department. The issues of negligence, fraud, litigation is become worse in the public sector in Malaysia due to they did not follow and obey with the standard and requirements provided.

\section{Problem Statement}

There are several issues raised regarding the implementation of records management practices into the auditing process. Lack of supporting documents. Records are the regardless of form that necessarily by the organization to provide the evidence and contribute to the decision making. The lack of supporting documents and records in the organization impose the risk in terms of unreliability to the transaction and fraud in the organization. This issue occurred when they do not have any supporting documents or additional documents to support the records or information from the document statement such as financial statement, especially in the audit process [1]. For organizations failing to produce records or documents on request, the maximum penalty for being guilty of an offense (as stated in the Companies Act) is only 2,000 Malaysian Ringgit (approximately equivalent to sterling 285 [2]. Integrated records management and corporate governance not yet being practices. Records Management is the activator to the success of corporate governance due to the added value of risk management, ease of auditing process either for internal and external inspection. However, Isa [3] claimed that, there is no integrated relationship between records management and corporate governance being practices to date. Therefore, this issue become the reasons on the increase number of fraud especially in auditing process and it can humiliate the institutional audits' image as they are the body that responsible to track and keep each of the financial statement for the evidence and reference in future.

Due to the financial global crisis, various corporate failures for example the collapse of Enron and WorldCom4, and in South Africa, the collapse of Saambou, Fedsure and Fidentia, due to the lack of concern by the public on the effective boards or management, the significance of corporate governance in both the public and private sectors has been increasingly recognized [4].

Reluctant to embrace the contribution of records management towards risk mitigation. Records management facilitate the corporate governance to mitigate the risk occurred in auditing process 
for example if there is intention to do the fraud on the business and activities in the organization, there are less likely to do so because of there are legislation requirements strictly implemented in the records management procedure such as each of the activities and process, there are needs of financial statement and documentation along with the authorization such as the signature. Therefore, they also can minimize the issues of false accusation to the innocent people that being accused to do the fraud and white-collar crime. Unfortunately, research found that some areas of public administration are not consider to embrace the contribution that records management can make to achieve good governance and accountability [2, 5]. Smallman [6] regards risk as the translation of uncertainty which stems from the lack of information about some phenomenon. Egbuji [7] identifies the risks associated with records as "loss of revenues, assets or business; loss of legal rights; exposure to losses and penalties in litigation or investigation; and violations of the law", for which the researcher suggests a comprehensive record management program to minimize business and legal risk in accordance of this research that gives the overview about the records management's contribution towards the risk mitigation. Normally, the risk that always happen in the organization for instances the negligence of employee in premature disposal, the unauthorized access to disclosure information that realized them about the significance of the records in support the evidence.

Records management not regarded as essential for good governance.

In South Africa, records management is often not regarded as essential for good governance in the public sector [8]. The audit committee normally provides the documentation such as financial statement to the auditor as only the requirements and rules of the organization when necessary, however, they are not aware and concern about the process and legislative requirements in the emerging of creation until the last value stages in the records.

\section{Research Objectives}

This paper attempts to address the need of supporting documents or records in the auditing process, to explore the relationship between records management and corporate governance, to investigate the contribution of records management towards risk mitigation and to analyse the general reports in relation to recordkeeping.

\section{Research Questions}

This research questions will help to address the problems or issues raised:

- What is the supporting documents or records in the auditing process?

- How is the relationship between records management and corporate governance?

- What is the contribution of records management towards risk mitigation?

- How are the reporting trends in relation to record-keeping?

\section{Literature Review}

ISO 9001 defines records as "A document that contains objective evidence which shows how well activities are being performed or what kind of result are being achieved. Records served as the legislative requirements that covered all the policy and standard designated by the government.

\section{Supporting Documents}

Without records, the organization indeed do not have any evidence about their operations and transaction due to not comply with the standard. Nationally, laws like The National Records and Archives Act [9] the Access to Information Act [10] and The Public Procurement and Disposal of Public Assets Act [11] The Local Government Act [12] among others, require that public entities keep, maintain and manage records using the guidelines laid down. This is because, the standardization of policy among the public sector is necessary to avoid any litigation issues. Ahimbisibwe [13] mentioned on one of the key ways in which organizations are held accountable for their actions is through evidence of business transactions in the form of records. The lack of attention and awareness about the significance of records exists the ethical issues which not concern with the legislative requirements.

\section{Records Management and Corporate Gov- ernance}

Ngoepe [14] agreed that corporate governance was therefore introduced to ensure that the agents of the owners of companies (directors and in the case of the public sector, the director-general) control their entity in ways that will serve the interests of the shareholders (owners and investors or in the case of the public sector: ministers, mayors and the public). The director is responsible to manage the people in the organization while the shareholder has the right to appoint the director. The transparency and accountability of the director in corporate governance are really necessary and needs to manage the entity and facilitate the right decision making in order to mitigate the risk and problem in the governance. The relationship of records management and corporate governance enable the evidence of the records achieve the accessibility, integrity, reliability and authenticity due to records management covered all legislative requirements and policy developed by the government. A close working relationship between these structures can improve the effectiveness of corporate governance [15]. According to Wamukoya [16], the need for records and the role of record keeping operate in three distinct domains, namely: the business domain, the accountability domain and cultural domain. These three areas will success and achieve the good governance in accordance of the proper means of records management

\section{Records Management towards Risk Miti- gation}

Risk and danger is the probability circumstances that occurred in any kind of places. Risk is often characterized by uncertainty and probability of an event's occurrence [17]. Risk is the translation of uncertainty which stems from the lack of information about some phenomenon [6] while, risk management responsible to identify, monitor, assessing and controlling the risk in the organization. Risk normally occur in terms of people, management and from the documentation and record keeping itself. The lack of record keeping in operations can impose to the risk.

\section{Records Management for Good Gov- ernance}

Good governance can be defined as the ability to manage the entity and enable to make the right decision making in order to serve the accountability and transparency to the country. Good governance exists when the corruption and fraud could be minimized with the implementation of a good team and comply with the standard and policy. A study by the World Bank in 1989 linked 
good governance to leadership, accountability, access to records, among others [18]. Good governance comprises of the commitment and good leadership from the director and stakeholder to manage the entity in the organization and serves the right decision making. Chinyemba [19] contends that good governance, accountability and transparency are the basis of productive relationships with stakeholders and are underpinned by records that are reliable and authentic. Good governance has eight major characteristics which are participatory, consensus oriented, accountable, transparent, responsive, effective and efficient, equitable and inclusive and follows the rule of law [20]. All of the necessary requirements assure that corruption is minimized, the views of minorities are taken into account and that the voices of the most vulnerable in society are heard in decision-making. As Barac [21] would concur, good governance is thus reliant upon the introduction and maintenance of mechanisms to promote that behaviour and performance of management which are in the interests of the stakeholders of the organization

\section{Methodology}

Population in this study is the staff at the institution that serves as the quality unit in one of the university in Malaysia. The population comprises of 40 auditors and 20 secretariats of the organization; therefore, the interview will be conducted with any potential respondent which expertise on that fields and job scope. The questions contained of two sections which is structured and semi structured questions. This study also applied survey as research instrument. Face to face interview is the main part in this study to get the findings as well as the observation of the general report of this quality unit to participated in the survey.

Qualitative method is the best way to choose in this research by considering the proposed objectives, problem statement and literature review of the study. The interview session is the method that will be considered to get the actual result and findings based on the $(5 \mathrm{~W} 1 \mathrm{H})$, What, Who, Where, Why, How and When.

In Figure 1, there are five independent variables in this study that represent the Implementation of Records Management Practices into the Auditing Process.

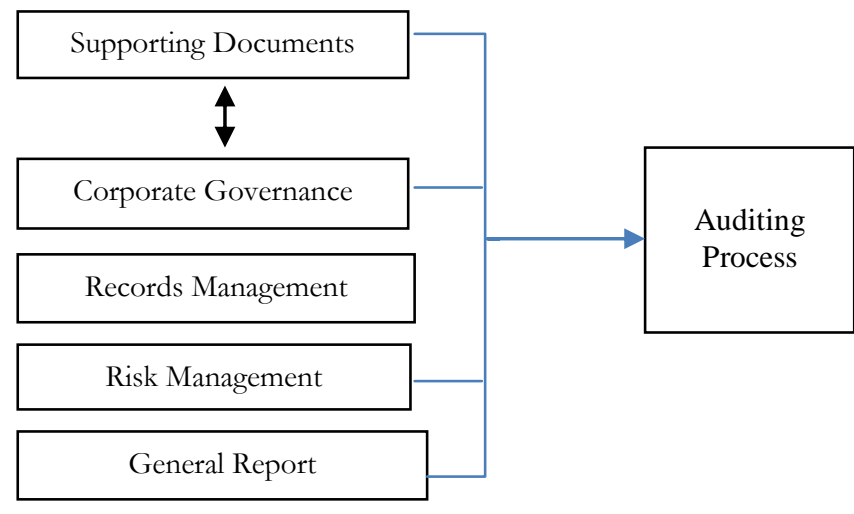

Independent Variables

Dependent Variable

Figure1: Conceptual Framework for Implementation of Records Management Practices into the Auditing Process.

\section{Data Collection and Analysis}

From the research instrument, data will be collected through interview and observation of the general report in relation on recordkeeping of the organization. Interview allows researcher to interact and generate ideas with the interviewee whereas this session included structured and semi structured questions. From the interview, any issues and genuine problem can be seen in the organization based on the problem statement developed and future research can be made at the end of this study to solve the problem. In structured interview, the interviewer follows a set pattern of ques- tions on the interview questionnaire while semi structured interview is a series of open ended questions. Data analysis technique used is ATLAS.ti which is the software that generates the findings from the qualitative research developed from the interview questions.

\section{Conclusion}

This study plays its roles to get the findings and results from the effectiveness of records management practices in the auditing process. This proposal is the preliminary investigation to investigate the records management practices in the auditing process as well as to analyse strategy to strengthen this fields and performance through the risk management in records management practices. The reader can analyse the significance of the records management practices in the auditing process in order to support the financial statement, good governance in administration, support litigation and achieve the reliability, authenticity, accountability and transparency in the organization. Based on this study, auditing process in terms of monitor and inspect the governance and transaction of documents need the policy and standard requirements that covered the creation, use, maintain and disposal process so that to achieve the efficiency of the governance in manage the records and evidence. From the literature review, particularly, the reader can analyse and make assumption that records management practices exist from the old civilization in the form of their culture since today but in different terms, process and skills. Therefore, this study is the platform to acknowledge the reader and researcher about the significance of this area.

\section{References}

[1] Nel, T. Audit findings and records management in the public sector. Paper read at DBS. document and records management conference, Midrand (South Africa). 2011, 19-21 September.

[2] Zawiyah Mohammad Yusof. "Nurturing attitudes for records management in Malaysian financial institutions", Records Management Journal. 2009; 19(3):218 - 230.

[3] Isa, A. M., Records management and the accountability of governance. PhD Thesis. Glasgow, University of Glasgow. 2009. Retrieved from http://theses.gla.ac.uk/1421/.

[4] Truter, M. Implementation of enterprise risk management as a tool for improving corporate governance within the public sector. Midrand, University of South Africa: MBL Dissertation. 2007.

[5] Australian National Audit Office. Record keeping in large Commonwealth organisations. Canberra: Australian National Audit Office. 2003. Retrieved from www.anao.gov.au/uploads/documents/200304_Audit_Report_7.pdf.

[6] Smallman, C. Knowledge management as risk management: a need for risk management, Risk Management: An International Journal. 1999;1(4): 7-20.

[7] Egbuji, A. "Risk management of organisational records", Records Management Journal. 1999; 9(2): 93-116.

[8] AGSA (Auditor-General of South Africa). Strategic plan and budget of the Auditor-General for 2010-2013. Pretoria: AGSA. 2010. Retrieved from http://www.agsa.co.za/Portals/1/STRATEGIC\%20PLAN\%20\&\%2 0BUDGET\%202010-13.pdf.

[9] The National Records and Archives Act. Uganda. 2001.

[10] Access to Information Act. "Uganda Printing and Publishing Corporation, Entebbe, by Order of the Government", Uganda Gazette No. 42 Volume XCVIII. 2005.

[11] The Public Procurement and Disposal of Public Assets Act. Uganda UPPC, Entebbe, by Order of the Government Gazette No. 3, Volume XCVII, UG. 2003.

[12] The local governments Act. Uganda.1997. Retrieved from www.ulii.org/ug/legislation/ consolidated-act/243.

[13] Ahimbisibwe, R. T. A. "Procurement records compliance, effective risk management and records management performance Evidence from Ugandan public procuring and disposing entities", Records Management Journal. 2016; 26(1): 83-101.

[14] Ngoepe, M. S. Fostering a framework to embed the records management function into the auditing process in the South African 
public sector. 1-247. 2012. Retrieved from http://uir.unisa.ac.za/bitstream/handle/10500/15418/thesis_ngoepe_ ms.pdf?sequence $=1$.

[15] Rezaee, Z. The importance of internal audit opinions. Internal Auditors, April. 47-50. 2010.

[16] Wamukoya, J. Records and archives as a basis for good government: implications and challenges for records managers and archivists in Africa. Records Management Journal. 2000; 10(1): 23-33.

[17] International Standards Organisation. ISO 31000:2009: Risk Management -Principles and Guidelines, ISO, Geneva. 2009.

[18] Akotia, P. Consequences of failure to manage public sector financial records. ESARBICA Journal. 2005; 24: 3-20.

[19] Chinyemba, A. Fostering accountability in institutions of higher learning. Paper read at XXI ESARBICA Conference, Maputo (Mozambique), 6-10 June. 2011. Retrieved from http://www.esarbica.org/Chinyemba.pdf.

[20] ESCAP (Economic and Social Commission for Asia and the Pacific). What is Good Governance? United Nations. 2011. Retrieved from http://www.unescap.org/sites/default/files/goodgovernance.pdf-escap 2011.

[21] Barac, K. Corporate governance in the public sector. Auditing SA 2001. Retrieved from http://www.saiga.co.za/publicationsauditingsa.htm. 